\title{
Risk Stratification of Coronary Heart Disease in Postmenopausal Women Using Framingham Scale in Eastern Nepal
}

\author{
Sujeeta Bajracharya1 ${ }^{1}$ Bijendra Kumar Rai ${ }^{2}$, Rajani Giri² and Rinku Joshi ${ }^{3}$
}

\author{
${ }^{1}$ Department of General Practice and Emergency Medicine, Nepalese Army Institute of Health Sciences, \\ Shree Birendra Hospital, Chhauni, Kathmandu, Nepal \\ ${ }^{2}$ Department of General Practice and Emergency Medicine, B.P. Koirala Institute of Health Sciences, \\ Dharan, Nepal \\ ${ }^{3}$ Department of Internal Medicine, Nepalese Army Institute of Health Sciences, Shree Birendra Hospital, \\ Chhauni, Kathmandu, Nepal
}

ABSTRACT
Introduction: Cardiovascular disease (CVD) is one of the leading causes of mortality and morbidity in
both developed and developing countries. CVD risk rises to double fold in women after menopause. We
aim to stratify menopausal women of our region for having coronary heart disease in next 10 years.
Methods: One year cross sectional study was conducted in General Out Patient Department (GOPD) of a
tertiary care centre of Eastern Nepal. The Standard ATP calculator was used and the relevant necessary
data was introduced into the calculator and the automated result was collected.
Results: Among 272 participants, above $50 \%$ had Framingham score 1 to $5 \%$. And the risk was greater
within first five years after menopause in 50 to 59 years of age group. Similarly, with advancing age and
longer duration of menopause the risk became significantly higher.
Conclusions: Besides the established risk factors for CVD, postmenopausal state is additional risk for
women and this study emphasises this factor as risk of CVD even in our set up.
Keywords: Cardiovascular disease; menopause; Framingham score; postmenopausal women

Correspondence: Sujeeta Bajracharya, Department of Emergency Medicine and General Practice, Nepalese Army Institute of Health Sciences, Shree Birendra Hospital, Chhauni, Kathmandu, Nepal. Email: sujeeta.bajracharya@gmail.com

DOI: http://dx.doi.org/10.3126/mjsbh.v17i2.19935

Submitted on: 2018-05-20

Accepted on: 2018-06-23

This work is licensed under creative common license:

http://creativecommons.org/licenses/by-nc-nd/4.0/ C MJSBH 2018 


\section{INTRODUCTION}

Cardiovascular disease (CVD) has been the leading cause of mortality and morbidity of both men and women in developed as well as developing countries. CVD refers to disease affecting blood vessels and heart; and usually atherosclerosis associated. ${ }^{1}$ Atherosclerotic plaques are thickened intima with various mixtures of fibrous tissues, cells, and lipid deposition with chronic inflammation..$^{2-4}$ CVD risk factors are categorised into major independent risk factors and predisposing factors including several lifestyle variables and laboratory parameters. ${ }^{5}$ The incidence and prevalence of coronary artery disease varies with the life cycle of women. The risk is lower in premenopausal state and increases in postmenopausal state. The offspring's of Framingham heart study who were gynaecologically normal, and were not taking any hormones showed that menopause is positively correlated with LDL cholesterol and decreased LDL particle size. ${ }^{6}$ CVD accounts for one third of all deaths and the rate is even higher for South Asian women. ${ }^{7}$

In country like Nepal, elderly women are under privileged, less literate, less health aware and health professionals are weakly concerned of advancing cardiovascular risk in this age group. American Heart Association (AHA) survey reveals that many (38\%) women underestimate the importance of CVD risk and that this issue is not often discussed. This loses the opportunity to prevent CVD mortality and morbidity by lifestyle modifications. ${ }^{8}$ Our study sets out to identify the risk score using Framingham risk assessment tool to predict the chance of having coronary heart disease in next 10 years. Here the subjects will get a chance to look at their future risk of developing coronary heart disease and the chance for timely intervention like life style modification and therapeutic intervention to prevent cardiovascular event.

\section{METHODS}

This was a year long observational study conducted in General Out Patient Department of tertiary care centre of Eastern Nepal conducted from $1^{\text {st }}$ Oct 2013 to $30^{\text {th }}$ Sept 2014. With permission from ethical clearance board and with informed consent, postmenopausal women were interviewed. Postmenopause for this study purpose was defined as cessation of menstruation naturally for at least one year. Exclusion criteria were previously diagnosed heart disease, past history of stroke or transient ischaemic attack. Individuals meeting the criteria were interviewed using a semi standardised performa. Blood pressure was assessed one time at the right upper arm after a five min rest in the sitting position with a manual mercury sphygmomanometer. Biomedical tests (Fasting Total Cholesterol, High Density LipoproteinCholesterol, and Fasting Blood Sugar) was done using a fasting venous blood sample after $12 \mathrm{hr}$ fast at the central laboratory on a voluntary fee pay basis and reports were collected on patient's follow up visits. Framingham score was calculated using the downloaded version ATP Risk Estimator .xlsm 12001 updated. The relationship between age, duration of menopause in years smoking habit were cross tabulated with Framingham score, where Framingham score was the dependent variable. The results was classified as follows: Low risk- Less than $10 \%$ chance, Intermediate risk- $10 \%$ to $20 \%$ chance, High risk- more than $20 \%$ chance. All the data as recorded in the Performa was entered into the Excel database and was analysed by the SPSS -17 program.

\section{RESULTS}

This study included 272 post menopausal patients from $1^{\text {st }}$ Oct 2013 to $30^{\text {th }}$ Sept 2014 who presented 


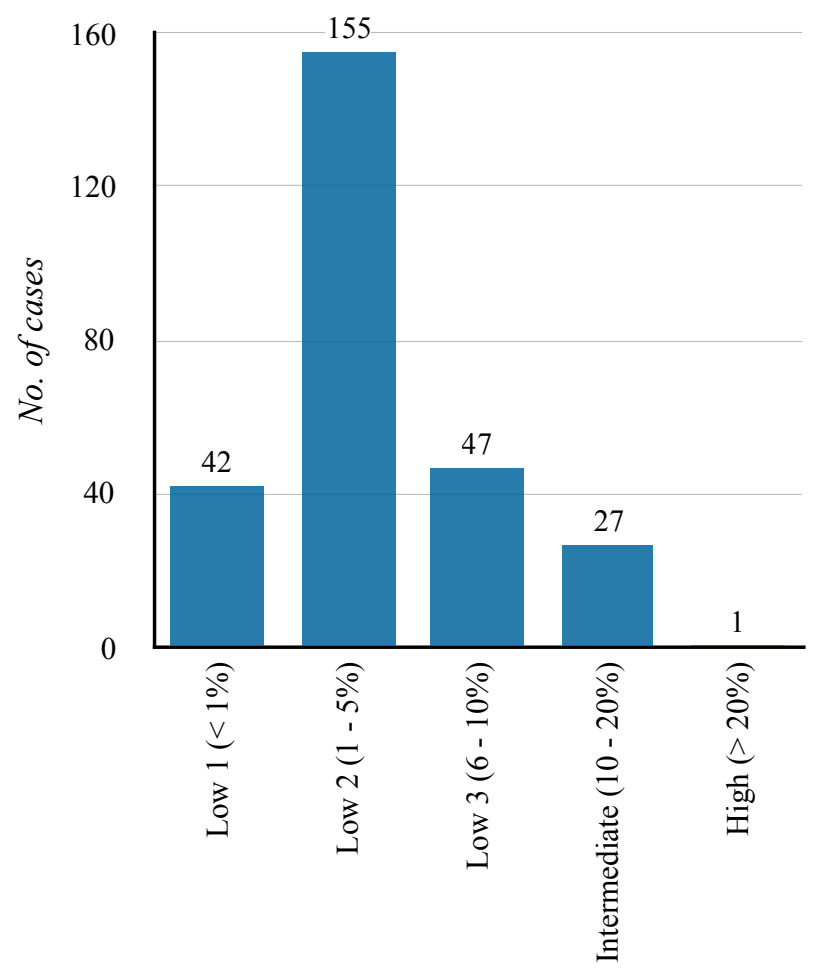

Framingham Score

Fig 1. Distribution of 10 Yrs CHD Risk Score (Framingham Score)

with complaints other than cardiac. The age ranged from youngest 50 years to oldest 80 years. The duration of menopause ranged from 1 to 26 years. The most common age to present in decades was in sixth decade $(\mathrm{n}=151)$ followed by seventh decade $(\mathrm{n}=83)($ Table1).

This study showed 5.5\% $(\mathrm{n}=15)$ had total cholesterol (TC) below $120 \mathrm{mg} / \mathrm{dl}, 75.36 \%$ $(\mathrm{n}=205)$ had between 121 to $210 \mathrm{mg} / \mathrm{dl}$ and $19.11 \%(\mathrm{n}=52)$ had above $211 \mathrm{mg} / \mathrm{dl}$. Within first five years of menopause 90 subjects had HDL-C $<39$ and the occurrence gradually decreased with the increase in DMY whereas those having HDL-C > 50 didn't gradually increase with increase in DMY (Table 3).

Similar pattern was recorded with age. Here $50 \%$ of the study population had SBP between 121 to 139 $\mathrm{mm} \mathrm{Hg}$ and the result was not statistically significant with DMY and age (Table 4). Among
Table 1. Physical and clinical characteristics of subjects $(n=272)$

\begin{tabular}{|l|r|}
\hline Characteristics & \multicolumn{1}{|c|}{ Mean(SD) } \\
\hline Age (Yrs) & $60.34(7.322)$ \\
\hline Age of menopause (Yrs) & $7.24(6.313)$ \\
\hline $\begin{array}{l}\text { Systolic blood pressure } \\
\text { (mm Hg) }\end{array}$ & $127.92(15.680)$ \\
\hline $\begin{array}{l}\text { Total Cholesterol (mg/dl) } \\
\text { HDL (mg/dl) }\end{array}$ & $38.38(3.819)$ \\
\hline $\begin{array}{l}\text { Framingham 10 years risk } \\
\text { estimation }\end{array}$ & 4.283 \\
\hline
\end{tabular}

total subjects, $\mathrm{n}=90,(30.73 \%)$ were diabetic and $\mathrm{n}=75$ had low risk, $\mathrm{n}=14$ had intermediate risk and $\mathrm{n}=1$ had high risk score and the result was statistically significant.

For Framingham score distribution, $89.7 \%$ of women had low risk $(<10 \%), 9.9 \%$ had intermediate risk $(10 \%-20 \%)$ and $0.4 \%$ had high risk $(>20 \%)$ of 10 yrs CHD risk. Similarly the occurrence of risk score was high in 50 to 59 years of life followed by 60 to 69 years and then 70 to 79 years. A significant number $(n=11)$ out of 27 of intermediate score were 70 to 79 years followed by $\mathrm{n}=7$ were 50 to 69 years (Fig. 1).

With increase in duration of menopause, the Low risk $(<10 \%)$ occurrence gradually decreased whereas the occurrence of High risk ( $>20 \%$ ) didn't increase in ascending order. From intermediate score group $(\mathrm{N}=27), \mathrm{n}=9$ had the longest duration of menopause (20 to 25 years) (Table 4 ).

The cross tabulation of TC and Framingham score showed statically significant result with $\mathrm{n}=205$ having TC $121-210 \mathrm{mg} / \mathrm{dL}$ and $\mathrm{n}=52$ having $>211 \mathrm{mg} / \mathrm{dL}$ and one subject from this group had high risk score (Table 6). The cross tabulation between HDL-C and Framingham score was not statically significant. Among $t=272$, 


\begin{tabular}{|c|c|c|c|}
\hline \multicolumn{4}{|c|}{ Table 2. Variables of the participants } \\
\hline Variables & & Frequency & Percentage \\
\hline \multirow{4}{*}{$\begin{array}{l}\text { Age } \\
\text { (Yrs) }\end{array}$} & $50-59$ & 151 & 55.5 \\
\hline & $60-69$ & 83 & 30.5 \\
\hline & $70-79$ & 35 & 12.9 \\
\hline & $80-89$ & 3 & 1.1 \\
\hline \multirow{5}{*}{$\begin{array}{l}\text { Duration of } \\
\text { Menopause } \\
\text { in Years } \\
\text { (DMY) }\end{array}$} & $1-5$ & 147 & 54.0 \\
\hline & $6-10$ & 51 & 18.8 \\
\hline & $11-15$ & 35 & 12.9 \\
\hline & $16-20$ & 29 & 10.7 \\
\hline & $21-25$ & 10 & 3.7 \\
\hline \multirow[t]{4}{*}{ Religion } & Buddhist & 12 & 4.4 \\
\hline & Christian & 24 & 8.8 \\
\hline & Hindu & 212 & 77.9 \\
\hline & Kirat & 24 & 8.8 \\
\hline \multirow[t]{4}{*}{ Education } & Illiterate & 147 & 54 \\
\hline & Primary & 85 & 31.3 \\
\hline & Secondary & 24 & 8.8 \\
\hline & Higher & 16 & 5.9 \\
\hline \multirow[t]{5}{*}{ Occupation } & $\begin{array}{l}\text { Home } \\
\text { maker }\end{array}$ & 118 & 43.4 \\
\hline & Farmer & 74 & 27.7 \\
\hline & Business & 34 & 12.5 \\
\hline & Employed & 13 & 4.8 \\
\hline & Pension & 33 & 12.1 \\
\hline \multirow[t]{2}{*}{ Diet } & $\begin{array}{l}\text { Non- } \\
\text { vegeterian }\end{array}$ & 249 & 91.5 \\
\hline & Vegeterian & 23 & 8.5 \\
\hline \multirow[t]{2}{*}{ Smoking } & Yes & 194 & 71.3 \\
\hline & No & 78 & 28.7 \\
\hline \multirow[t]{3}{*}{$\begin{array}{l}\text { Duration of } \\
\text { exercise }\end{array}$} & $\begin{array}{l}\text { Less than } \\
150 \mathrm{~min} / \\
\text { week }\end{array}$ & 12 & 4.4 \\
\hline & $\begin{array}{l}\text { More than } \\
150 \mathrm{~min} / \\
\text { week }\end{array}$ & 5 & 1.8 \\
\hline & $\begin{array}{l}\text { No } \\
\text { exercise }\end{array}$ & 255 & 93.8 \\
\hline \multirow{2}{*}{$\begin{array}{l}\text { Weight in } \\
\text { Kgs }\end{array}$} & $40-49$ & 28 & 10.3 \\
\hline & $50-59$ & 151 & 55.5 \\
\hline
\end{tabular}

\begin{tabular}{|c|c|c|c|}
\hline Variables & & Frequency & Percentage \\
\hline & $60-69$ & 63 & 23.2 \\
\hline & $70-79$ & 26 & 9.6 \\
\hline & $80-89$ & 4 & 1.5 \\
\hline \multirow{5}{*}{$\begin{array}{l}\text { Waist in } \\
\text { Cms }\end{array}$} & $60-69$ & 23 & 8.5 \\
\hline & $70-79$ & 154 & 56.6 \\
\hline & $80-89$ & 72 & 26.5 \\
\hline & $90-99$ & 18 & 6.6 \\
\hline & $100-109$ & 5 & 1.8 \\
\hline
\end{tabular}

$\mathrm{n}=163$ had HDL-C $<39$ and $\mathrm{n}=1(\mathrm{t}=163)$ had high risk score (Table 4).

\section{DISCUSSION}

Several studies on increasing cardiovascular risk in post-menopausal women put insight in importance of early screening and timely intervention for primary prevention. Here in this study Framingham Risk assessment tool has been used to calculate the 10 years CHD risk and traditional CVD risk factors have been assessed. Among 272 subjects, more than three quarters $n=244$ subjects $(89.7 \%)$, had projected 10 years risk of CHD risk $<10 \%$. The outcome was quite different in a comparative study with total 691 subjects aged 30 to 70 years, $n=59$ subjects $(8.5 \%)$ had projected 10 year coronary heart disease risks $>30 \%$, and 291 (42.1\%) had risks $>15 \%{ }^{9}$

The mean Framingham risk estimation of participants in this study was 4.28 which are comparable with a study done on Iranian postmenopausal women with mean risk 1.46 . The estimated 10 years risk for CHD was greater in this study, which could be because the mean age of the participants was high (mean age $=60.34$ years) and it has adopted the calculator from the original Framingham study but the performance of the scale in Asian population is not clear. ${ }^{10}$ This study illustrates $20 \%$ of study population had $\mathrm{TC}>211 \mathrm{mg} / \mathrm{dL}$ and the occurrence $(\mathrm{n}=146)$ of $\mathrm{TC}>121 \mathrm{mg} / \mathrm{dL}$ was in age group 50 to 59 years. 
Table 3: Relation between Duration of Menopause and total cholesterol and HDL-C

\begin{tabular}{|c|c|c|c|c|c|c|c|}
\hline \multirow[t]{2}{*}{ Lipid profile } & \multirow[t]{2}{*}{ Values in $\mathrm{mg} / \mathrm{dl}$} & \multicolumn{5}{|c|}{ DMY (Yrs) } & \multirow{2}{*}{$\begin{array}{c}p \\
\text { value }\end{array}$} \\
\hline & & 1 to 5 & 6 to 10 & 11 to 15 & 16 to 20 & 21 to 25 & \\
\hline \multirow{4}{*}{$\begin{array}{l}\text { Total } \\
\text { cholesterol }\end{array}$} & $<120$ & 5 & 3 & 3 & 2 & 2 & \multirow[t]{4}{*}{0.258} \\
\hline & $121-210$ & 109 & 40 & 28 & 23 & 5 & \\
\hline & $>211$ & 33 & 8 & 4 & 4 & 3 & \\
\hline & Total & 147 & 51 & 35 & 29 & 10 & \\
\hline \multirow[t]{4}{*}{ HDL } & $<39$ & 90 & 24 & 22 & 21 & 6 & \multirow[t]{4}{*}{0.260} \\
\hline & $40-49$ & 56 & 27 & 13 & 7 & 4 & \\
\hline & $>50$ & 1 & 0 & 0 & 1 & 0 & \\
\hline & Total & 147 & 51 & 35 & 29 & 10 & \\
\hline
\end{tabular}

The highest number of subjects $(\mathrm{n}=142)$ developed this after one to five years of menopause and this was 54\% rise in CHD risk and was found to decline gradually in the following ages. A study by Mathews et al. in SWAN (Study of Women's Health across the Nation) discussed that total cholesterol, LDL-C, HDL-C changes with menopause in first one year. And several studies also have shown a strong positive relationship of total cholesterol (TC) above $180 \mathrm{mg} / \mathrm{dl}$ with CHD risk and death. ${ }^{11,12}$

On the basis of those studies, the rise in CHD risk in first few years of menopause is implacable to the

Table 4: Relation between DMY, Total cholesterol, HDL-C and Framingham score

\begin{tabular}{|c|c|c|c|c|c|}
\hline Variables & & Low $(<10 \%)$ & Intermediate (10-20\%) & High $(>20 \%)$ & p-value \\
\hline \multirow{6}{*}{$\begin{array}{l}\text { DMY } \\
\text { (Yrs) }\end{array}$} & $1-5$ & 140 & 7 & 0 & \multirow[t]{6}{*}{$<0.001$} \\
\hline & $6-10$ & 47 & 4 & 0 & \\
\hline & $11-15$ & 31 & 3 & 1 & \\
\hline & $16-20$ & 25 & 4 & 0 & \\
\hline & $21-25$ & 1 & 9 & 0 & \\
\hline & Total & 244 & 27 & 1 & \\
\hline \multirow{4}{*}{$\begin{array}{l}\text { Total Cholesterol } \\
\text { (mg/dl) }\end{array}$} & $<120$ & 14 & 1 & 0 & \multirow[t]{4}{*}{$<0.001$} \\
\hline & $121-210$ & 194 & 11 & 0 & \\
\hline & $>211$ & 36 & 15 & 1 & \\
\hline & Total & 244 & 27 & 1 & \\
\hline \multirow{4}{*}{$\begin{array}{l}\text { HDL-C } \\
\text { (mg/dl) }\end{array}$} & $<39$ & 44 & 18 & 1 & \multirow[t]{4}{*}{0.741} \\
\hline & $40-49$ & 98 & 9 & 0 & \\
\hline & $>50$ & 2 & 0 & 0 & \\
\hline & Total & 244 & 27 & 1 & \\
\hline
\end{tabular}


postmenopausal women of this study group. And this issue is addressed by ATPIII of the National Cholesterol Education Program (NCEP) guideline which suggests that if one's FRE is $<10 \%$ with $2+$ risk factors, one's LDL goal should be $<130$, and individuals with $\mathrm{FRE}<10 \%$ with 0 to 1 risk factors should have a LDL goal of $<160$.

Similarly, several other studies have established a powerful protective inverse relation between increasing HDL and incidence of CHD. Low HDL concentrations less than $40 \mathrm{mg} / \mathrm{dl}$ have a greater risk for CHD. ${ }^{13}$ In this study, 59.92\% $(\mathrm{n}=163)$ (total $n=272$ ) of participants had HDL less than 39 , among this $(\mathrm{n}=92)$ had 10years CHD risk between $1 \%$ to $5 \%$. Who had menopause within last one to five years $(n=90)$ had HDL $<39 \mathrm{mg} / \mathrm{dL}$. This result is comparable with the result from a study done on Iranian postmenopausal women which showed only $22.4 \%$ of participants with HDL less than 40. This indicates that the women from our region are at higher risk for CHD than Iranian women.

\section{CONCLUSIONS}

The Framingham risk was comparatively greater within first five years after menopause in 50 to 59 years of age group. With advancing age and longer duration of menopause the Framingham risk became gradually higher. So, postmenopausal state is an additional risk for CVD in women even in our set up.

To cite this article: Bajracharya S, Rai BK, Giri R, Joshi R. Risk stratification of coronary heart disease in postmenopausal women using Framingham scale in Eastern Nepal. MJSBH. 2018;17(2):51-7

Conflict of Interest: None declared

\section{REFERENCES}

1. The medical news. What is cardiovascular disease? 2011 Jan 25.

Available from: URL: http://www.news-medical.net/health/What-is-Cardiovascular-Disease.aspx

2. Tabas I, Williams KJ, Boren J. Sub endothelial lipoprotein retention as the initiating process in atherosclerosis: update and therapeutic implications. Circulation. 2007;116:1832-44.

DOI: https://doi.org/10.1161/CIRCULATIONAHA.106.676890PMid:17938300

3. Witztum JL. The role of oxidized LDL in the atherogenic process. J Atheroscler Thromb. 1994;1:71-5. DOI: https://doi.org/10.5551/jat1994.1.71 PMid:9222872

4. Barrett-Connor E. Heart disease in women. Fertil Steril. 1994;62(2):127-32.

PMid:7958006

5. Grundy SM, Pasternak R, Greenland P, Smith S, Fuster V. Assessment of Cardiovascular Risk by Use of Multiple-Risk-Factor Assessment Equations. A Statement for Healthcare Professionals from the American Heart Association and the American College of Cardiology. J Am Coll Cardiol. 1999;34:1348 -59 .

DOI: https://doi.org/10.1016/S0735-1097(99)00387-3 
6. Manson JW, Spelsberg A. Risk modification in the diabetic patient. In: Manson JE, Ridker PM, Gaziano JM, et al, eds. Prevention of Myocardial Infarction. New York: Oxford University Press, Inc. 1996:241273.

7. Jackson G. Coronary artery disease and women. British Medical Journal. 1994 Sep;309(6954):555. DOI: https://doi.org/10.1136/bmj.309.6954.555PMid:8086940ＰMCid:PMC2541423

8. Wikipedia. [Online]. 2011 [cited 2011 Jan 25]; Available from: URL: http://en.wikipedia.org/ wiki/Nepal

9. Jones AF, Walker J, Jewkes C, Game FL, Bartlett WA, Marshall T, et al. Comparative accuracy of cardiovascular risk prediction methods in primary care patients. Heart 2001;85:37-43.

DOI: https://doi.org/10.1136/heart.85.1.37PMid:11119458 PMCid:PMC1729574

10. D'Agostino RB, Russell MW, Huse DM, Ellison RC, Silbershatz H, Wilson PW, et al. Primary and subsequent coronary risk appraisal: new results from the Framingham study. American heart journal. 2000 Feb;139(2):272-81.

DOI: https://doi.org/10.1016/S0002-8703(00)90236-9

11. Matthews KA, Crawford SL, Chae CU, Everson-Rose SA, Sowers MF, Sternfeld B, et al. Are changes in cardiovascular disease risk factors in midlife women due to chronological ageing or to the menopausal transition. Journal of the American College of Cardiology. 2009 Dec;54(25):2366-73.

DOI: https://doi.org/10.1016/j.jacc.2009.10.009PMid:20082925 PMCid:PMC2856606

12. Neaton JD, Blackburn H, Jacobs D, Kuller L, Lee DJ, Sherwin R, et al. Serum cholesterol level and mortality findings for men screened in the multiple risk factor intervention trial. Multiple risk factor intervention trial research group. Arch Intern Med. 1992;152(7):1490-1500.

DOI: https://doi.org/10.1001/archinte.1992.00400190110021ＰMid:1627030

13. MRC/BHF heart protection study of cholesterol lowering in 20536 high risk individuals: a randomised controlled clinical trial. Heart Protection Study Collaborative Group. Lancet 2002;360(9326):7-22. DOI: https://doi.org/10.1016/S0140-6736(02)09327-3 